\title{
Molecular characterization of Hydrellia lagarosiphon, a leaf mining biological control agent for Lagarosiphon major, reveals weak variance across large geographic areas in South Africa
}

\author{
Rosie Mangan ${ }^{\mathrm{a}, \mathrm{b}, *}$, James C. Carolan ${ }^{\mathrm{c}}$, Jan-Robert Baars ${ }^{\mathrm{a}}$ \\ ${ }^{a}$ BioControl Research Unit, School of Biology and Environmental Science, University College Dublin, Dublin 4, Ireland \\ ${ }^{\mathrm{b}}$ Department of Zoology and Entomology, Rhodes University, PO Box 94, Grahamstown 6140, South Africa \\ ${ }^{\mathrm{c}}$ Department of Biology, Maynooth University, Maynooth, Co. Kildare, Ireland
}

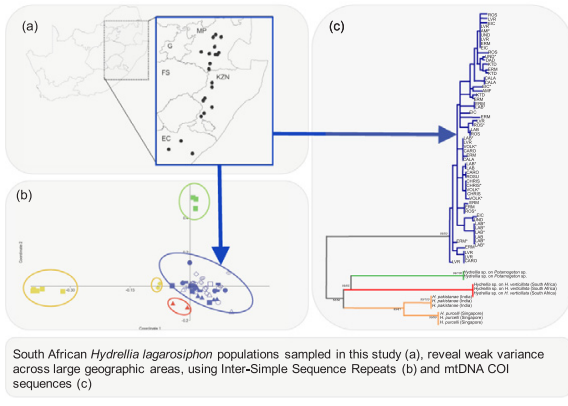

\section{Introduction}

Native range exploration to identify new biological control agents is technically difficult and time-consuming, yet it is the foundation on which all other elements of a successful biological research programme ultimately depend (Goolsby et al., 2006). During field surveys agents demonstrating a high degree of host specificity and damage efficacy are prioritized. However, due to logistical and technical constraints potentially favourable natural enemies are usually only collected from one or a small number of source populations. Selecting the natural enemy population for host range testing and eventual release is important, as it has become increasingly evident that insect species occurring across a wide geographical range are generally structured into genetically differentiated populations (Madeira et al., 2001; Rauth et al., 2011). Highlighting these biogeographical population level differences can help anticipate potential variation in an agent's climatic adaptations or host-related traits (Paterson et al., 2016), and this information can in turn guide the selection of a more effective and safe agent.
The aquatic plant African curly leaved waterweed, Lagarosiphon major (Ridl.) Moss ex Wager (Hydrocharitaceae) is a non-native, canopy forming macrophyte found in several European countries (Preston et al., 2002; Reynolds, 2002; Symoens and Triest, 1983; van Valkenburg and Pot, 2008) as well as New Zealand (McGregor and Gourlay, 2002) and Australia (Bowmer et al., 1995). In an attempt to establish a longterm control strategy for this vigorous and highly invasive plant, a biological control programme was initiated with surveys for natural enemies of L. major undertaken in South Africa between 2008 and 2011 (Baars et al., 2010; Earle et al., 2013). These field surveys revealed a suite of phytophagous natural enemies associated with $L$. major, mostly new to science, and include ephydrid flies, pyralid moths, and stemmining midges (Baars et al., 2010; Earle et al., 2013; Mangan and Baars, 2013). Of those found, Hydrellia lagarosiphon Deeming has been identified as the most promising candidate agent (Baars et al., 2010; Van Achterberg and Prinsloo, 2012). The fly is widely distributed under a range of climatic conditions throughout South Africa, indicating that if released the fly may establish well in new areas within the geographic

\footnotetext{
* Corresponding author at: Biological and Environmental Sciences, University of Stirling, Stirling FK9 4LA, UK.

E-mail address: manganrosemary@gmail.com (R. Mangan).
} 
Table 1

Sampling sites with geographical data and the hosts of 14 ephydrid fly populations in South Africa.

\begin{tabular}{|c|c|c|c|c|c|c|}
\hline Site (code) & Altitude (m, a.s.L.) & Latitude & Longitude & $n$ & Host plant(s) & Province \\
\hline Amersfort (AMF) & 1706 & $27^{\circ} 00^{\prime} 37.01$ & $29^{\circ} 50^{\prime} 27.66$ & 2 & L. muscoides & MP \\
\hline Cala (CALA) & 1187 & $31^{\circ} 31^{\prime} 26.90$ & $27^{\circ} 41^{\prime} 48.91$ & 3 & L. major & EC \\
\hline Carolina (CARO) & 1696 & $26^{\circ} 06^{\prime} 19.82$ & $30^{\circ} 07^{\prime} 30.27$ & 4 & L. major & MP \\
\hline Chrissiesmeer* (CHRIS) & 1655 & $26^{\circ} 32^{\prime} 15.02$ & $30^{\circ} 14^{\prime} 48.90$ & 3 & L. major & MP \\
\hline David Aucamp Dam" (DAD) & 1405 & $31^{\circ} 04^{\prime} 19.90$ & $28^{\circ} 19^{\prime} 40.45$ & 2 & L. major & EC \\
\hline Kubusi farm dam (LAB) & 605 & $32^{\circ} 33^{\prime} 52.01$ & $22^{\circ} 29^{\prime} 22.42$ & 10 & L. major & EC \\
\hline Elands irrigation canal \& river (EIC) & 1083 & $25^{\circ} 35^{\prime} 48.98$ & $30^{\circ} 27^{\prime} 54.32$ & 5 & L. major & KZN \\
\hline Ermelo dam \& wetlands (ERM) & 1690 & $26^{\circ} 32^{\prime} 39.37$ & $30^{\circ} 07^{\prime} 09.38$ & 11 & L. major \& L. muscoides & MP \\
\hline Khotso dam (KTD) & 1262 & $28^{\circ} 58^{\prime} 01.58$ & $29^{\circ} 30^{\prime} 05.23$ & 4 & L. major \& L. muscoides & KZN \\
\hline Lakenvlei (LVR) & 1876 & $25^{\circ} 36^{\prime} 23.60$ & $30^{\circ} 01^{\prime} 57.32$ & 8 & L. muscoides & MP \\
\hline Rosetta* (ROS) & 1459 & $29^{\circ} 18^{\prime} 18.92$ & $29^{\circ} 58^{\prime} 28.95$ & 6 & L. major & KZN \\
\hline Roadway (POT) & 1432 & $28^{\circ} 15^{\prime} 42.15$ & $29^{\circ} 58^{\prime} 28.88$ & 2 & Potamogeton spp. & KZN \\
\hline Underberg $^{*}$ (UND) & 1628 & $29^{\circ} 48^{\prime} 09.72$ & $29^{\circ} 23^{\prime} 3443$ & 3 & L. major \& L. muscoides & MP \\
\hline Volksrust farm dam* (VOLK) & 1660 & $27^{\circ} 16^{\prime} 56.95$ & $29^{\circ} 47^{\prime} 33.06$ & 4 & L. major & KZN \\
\hline
\end{tabular}

Prov: Province.

EC, Eastern Cape; MP, Mpumalanga; KZN, KwaZulu-Natal.

* Indicates sites where adult flies were also reared from pupae within infested plant materia.

range of the weed. Hydrellia lagarosiphon frequently attains high population densities and causes severe damage despite notable parasitism by braconid wasps in its native range (Baars et al., 2010; Van Achterberg and Prinsloo, 2012).

Following its discovery, the fly was taxonomically described and is morphologically distinguishable from other Hydrellia species based on variation in the male genitalia (Deeming, 2012). The emergence of molecular genetic fingerprinting techniques as a means of assisting the identification of insect species has highlighted that phenotypic differentiation does not always correlate with genetic diversification and a considerable proportion of biological diversity can be morphologically hidden (Herbert et al., 2004; Smith et al., 2006; Van Driesche and Bellows, 1996). Distribution records from the South African National Biodiversity Institute and published literature indicate $L$. major displays patchy distribution across a wide geographical range, with sites frequently isolated in terms of elevation and eco-region. The Drakensberg Mountains are the highest part of the Highveld in South Africa $(\sim 3500 \mathrm{~m}$ a.s.L.) dividing the Mpumalanga Province into two parts; the Highveld, north of Johannesburg ( $\sim 1700 \mathrm{~m}$ a.s.L.) consisting mainly of grassland and the lower altitude subtropical Lowveld consisting of mostly savanna habitat. The mountain range also isolates the KwaZuluNatal Province from Lesotho and the Free State Province. Given the large spatial scale covered during these field studies, as well as the range of eco-regions encountered, it is possible that genetic divergence will occur in fly populations that are completely isolated, or have restricted gene flow (Slatkin, 1985).

While the characterisation of morphological traits for the taxonomic description of new biological control agents is essential, obtaining a genetic perspective on population structure and inter- and intra-specific diversity is now widely practiced. Genetic markers can assist with taxonomic circumscription, the identification of species, subspecies and races and provide unambiguous taxonomic resolution to help interpret local biological adaptations on a population by population level (Moffat and Smith, 2015; Mound et al., 2010; Rauth et al., 2011; Vorsino et al., 2014). More significantly the presence of cryptic species which are difficult to resolve using morphological characteristics alone, highlights the potential benefits of employing genetic assessment prior to the selection of a potential biocontrol agent for both testing and release (Paterson et al., 2016; Toševski et al., 2013). In addition, the application of genetic marker based methods to problematic taxonomic groups, not only identifies cryptic species but can also resolve favourable trait distribution across populations (e.g. host specificity or climatic adaptations) and assist in the monitoring of biological agent control releases (Behura, 2006; Gariepy et al., 2007; Hufbauer et al., 2004; Moffat and Smith, 2015; Mound et al., 2010; Olivieri et al., 2008; Rauth et al.,
2011; Vorsino et al., 2014). This precautionary, but informed approach is essential in reducing unanticipated non-target effects and inefficient biocontrol and highlights the importance of testing agents on a population by population basis given that population specific biological traits and adaptations may exist (Paterson et al., 2016; Toševski et al., 2013). Therefore, obtaining genetic level insight is particularly relevant for biological control and the lack of genetic information prior to the field release of biological control agents has been implicated in the failure of some of these programmes (Hopper and Roush, 1993; Hufbauer and Roderick, 2005; Roderick and Navajas, 2003). It is also noteworthy that stringent species identification is now a requirement of numerous national biocontrol programmes (Goolsby et al., 2006) and that biocontrol release in Europe now requires genetic barcoding to underpin species identification (Bigler et al., 2005).

In this study, we investigated patterns of genetic diversity in $H$. lagarosiphon across South Africa using both nuclear microsatellite and mitochondrial DNA (mtDNA) markers to establish the levels of genetic variance across the large geographic area surveyed. This information will guide the selection of source populations for laboratory screening, indicating potential variation in an agent's climatic adaptation or hostrelated traits, and demonstrate the potential for effective dispersal into new environments.

\section{Materials and methods}

\subsection{Insect collection}

Hydrellia lagarosiphon populations were sampled from South Africa during field surveys and included sites from some of the most southerly records in Eastern Cape Province ( $\sim 750 \mathrm{~m}$ a.s.L.) to high altitude sites (1400-2000 m a.s.L.) in Mpumalanga Province (Table 1). Adult flies were collected at 14 sites where leaf-mining damage was evident. Host plants included the target plant $L$. major, as well as a species in the same genus Lagarosiphon muscoides Harv., and a Potomageton species on which ephydrid fly damage was also evident. These included individuals from three laboratory cultures (originating from Kubusi farm dam in the Eastern Cape, Chrissiesmeer in Mpumalanga, and Volksrust farm dam near the Mpumalanga-KwaZulu-Natal border) under evaluation to assess potential performance differences and preliminary host specificity between populations from different eco-regions. In addition, pupae were sampled directly from both $L$. major and $L$. mucsoides, reared to the adult stage and included in the analysis. Additional specimens were included in the analysis as outgroups; Hydrellia sp. indet. (reared on Hydrilla verticillata in South Africa), Hydrellia pakistanae Deonier originally collected in India and Hydrellia purcelli Deeming 
originally collected in Singapore (supplied by Angela Bownes, Agricultural Research Council, Plant Protection Research Institute, South Africa).

\subsection{DNA extraction}

All individuals were stored individually in $100 \%$ ethanol. DNA was extracted from 100 adult Hydrellia collected on Lagarosiphon species, Potamogeton sp., and Hydrilla verticillata using the Qiagen DNeasy Blood and Tissue kit (Qiagen GmbH, Hilden, Germany) following the manufacturer's protocol. DNA quality and concentration was measured using a NanoDrop ${ }^{\circledR}$ ND-1000 Spectrophotometer (Labtech Int., UK). These extractions were then stored at $-20{ }^{\circ} \mathrm{C}$ until required.

\section{3. mtDNA sequencing}

The cytochrome oxidase I (COI) region of the mitochondrial genome (mtDNA) was amplified for all samples. PCR reactions were carried out in $20 \mu \mathrm{l}$ volumes under the following conditions; $4 \mu \mathrm{l}$ of genomic DNA, $8.48 \mu \mathrm{l}$ of $\mathrm{ddH}_{2} 0,1.8 \mu \mathrm{l}$ of $\mathrm{MgCl}_{2}(25 \mathrm{mM}), 0.6 \mu \mathrm{l}$ of each primer $(10 \mu \mathrm{M}$ each; Nancy S (5'-CCCGGTAAAATTAAAATATAAAC-3') and LCO_Hym ( 5'-TATCAACCAATCATAAAGATATTGG-3') (Simon et al., 1994), $0.4 \mu \mathrm{l}$ dNTPs (10 mM each), $4.0 \mu \mathrm{l}$ 10X buffer (Promega) and $0.12 \mu \mathrm{l}$ of Taq polymerase. Thermal profiles started with an initial denaturing @ $94^{\circ} \mathrm{C}$ for $60 \mathrm{~s}$, followed by 32 cycles of $94^{\circ} \mathrm{C}$ for $60 \mathrm{~s}, 50{ }^{\circ} \mathrm{C}$ for $45 \mathrm{~s}$ and $72{ }^{\circ} \mathrm{C}$ for $60 \mathrm{~s}$. The cycle ended with one final extension of $240 \mathrm{~s}$ at $72{ }^{\circ} \mathrm{C}$. The PCR products were purified using the Novagen ${ }^{\circledR}$ Spinprep $^{\mathrm{TM}}$ PCR Cleanup Kit according to the manufacturer's protocol. The sequencing reactions were conducted at Macrogen Inc. (South Korea). Sequences were deposited in GenBank (Accessions MK164650 to MK164651).

\section{4. mtDNA sequences analyses}

Chromatogram contigs were assembled in Sequencher 4.2 (GeneCodes) and sequence alignments were proof read manually and aligned using Se-Al 2.0 (Rambaut, 2001). Phylogenetic analyses were conducted using MEGA 5 including the neighbor joining and maximum likelihood methods (Tamura et al., 2011). The haplotype diversity $(h)$, mean pairwise differences (MPD) and nucleotide diversity $(\pi)$ for each population were estimated using DnaSp. Ver. 5 (Librado and Rozas, 2009). Population structure was analysed using the Analysis of Molecular Variance (AMOVA) (Excoffier et al., 1992) and by calculating the $\mathrm{F}_{\mathrm{ST}}$ values (Hudson et al., 1992) between populations, using the Kimura two-parameter distance method (Kimura, 1980). The statistical significance was determined by performing 1000 permutations of the original data set using Arlequin 3.0 (Excoffier et al., 2005).

\subsection{Inter-simple sequence repeat PCR amplification}

ISSRs were conducted on 11 of the 14 populations using the universal primers 809 and 826 from University of British Columbia Nucleic Acid Protein Service Unit Primer set \#9 (Abbot, 2001), fluorescently labeled with 6-FAM dye. PCR reactions were carried out in $20 \mu \mathrm{l}$ volumes with primer concentration $0.8 \mu \mathrm{M}$ and $10 \mu \mathrm{l}$ of Promega Master Mix (Madison, WI, USA) (reaction concentration of $1 \mathrm{U}$ of Taq, $1.5 \mathrm{mM}$ $\mathrm{MgCl}_{2}$, and $0.2 \mu \mathrm{M}$ dNTPs) per reaction. $\mathrm{MgCl}_{2}$ was added to a final concentration of $2.5 \mathrm{mM}$. Thermal profiles started with an initial denaturing @ $94^{\circ} \mathrm{C}$ for $2 \mathrm{~min}$, followed by 35 cycles of $94^{\circ} \mathrm{C}$ for $30 \mathrm{~s}, 44^{\circ} \mathrm{C}$ for $45 \mathrm{~s}$ and $72{ }^{\circ} \mathrm{C}$ for $90 \mathrm{~s}$. The cycle ended with one final extension of $20 \mathrm{~min}$ at $72{ }^{\circ} \mathrm{C}$. Banding patterns generated by the labeled primers were visualized using capillary electrophoresis on an ABI 3130 genetic analyser at Stellenbosch University, Stellenbosch, South Africa. Every sample was replicated from the PCR step so there were two sets of binary data for each sample. Only peaks that were present in both replicates were used for further analyses. Bands that were only present in one of the replicates were treated as missing data.

\subsection{Inter-simple sequence repeat data analysis}

Electropherograms were analyzed using PeakScanner v. 1.0 (Applied Biosystems, Foster City, CA) using a medium level of peak smoothing. The analyzed data set was then exported into RawGeno v. 2.0-2 (Arrigo et al., 2009) using the RC v. 3.0.1 platform (The $\mathrm{R}$ Foundation for Statistical Computing, Vienna, Austria). The final binary data set was then used to conduct Principal Component analysis in PAST: Paleontological Statistics Package v. 1.94 (Hammer et al., 2001) using the Jaccard's Index to convert the binary data into a distance matrix. The percentage of polymorphism and expected heterozygosity $\left(\mathrm{H}_{\mathrm{E}}\right)$ were calculated for each population using GenAlex (Peakall and Smouse, 2006). The genetic differentiation between populations was determined using $\Phi_{\mathrm{ST}}$, a measure that allows intra-individual variation to be suppressed and is therefore ideal for comparing dominant binary data, with 10,000 permutations (Assoumane et al., 2013). Analysis of molecular variance (AMOVA) among and within populations and geographical regions was performed using GenAlex (Excoffier et al., 1992; Peakall and Smouse, 2006).

\section{Results}

\subsection{Sequence data, haplotypes and genetic diversity}

After excluding the ambiguously called base pairs at the beginning and ends of each sequence, a 608-bp portion of the COI mt DNA sequences was obtained for 67 Hydrellia collected on Lagarosiphon species $(\mathrm{n}=65)$ and Potamogeton sp. $(\mathrm{n}=2)$. A total of 47 different haplotypes were identified which were differentially distributed across the 14 populations sampled. Only six haplotypes were shared by at least two individuals and 41 were unique (Table 2). Of the six shared haplotypes, $\mathrm{H}_{4}$ was found within 7 populations (CALA, CARO, CHRIS, ERM, LAB, LVR, and VOLK) and $\mathrm{H}_{10}$ was found in 3 populations (CARO, LVR, and VOLK). The most common haplotype $\left(\mathrm{H}_{4}\right)$ was widespread and was represented in $16.4 \%$ of the sequenced individuals, $54 \%$ of the 13 populations, and all three provinces where Lagarosiphon species were surveyed. Of the 47 haplotypes present within the native populations, six haplotypes were present in the laboratory culture (Table 2). The haplotypes present in the laboratory culture were present in CALA, CARO, CHRIS, ERM, LVR, and VOLK. Haplotype diversity ranged from 0.800 (LAB) to 1.00 (for 11 of the populations), with an average of 0.970 for the 13 populations (Table 3 ). Nucleotide diversity $(\pi)$ ranged from 0.003 (VOLK) to 0.118 (DAD), with an average of 0.060 .

\subsection{Genetic relationships between populations}

Four distinct clades were resolved by the mitochondrial CO1 sequence analysis for 76 specimens, representing four different species on a variety of host plants (Fig. 1). One clade represents specimens collected on $L$. major and $L$. muscoides during the native range exploration for an agent for $L$. major. Several specimens were also represented in a separate clade and include all individuals collected on a Potamogeton species. Another clade denotes Hydrellia sp. specimens collected on Hydrilla verticillata in South Africa and the final clade represents $\mathrm{Hy}$ drellia pakistanae collected on $H$. verticillata in India and Hydrellia purcelli collected on $H$. verticillata in Singapore. The K2P genetic distances between haplotypes within the 13 populations collected on L. major and L. muscoides in South Africa ranged from 0.006 (CHRIS) to 0.065 (LAB) (overall mean within population, 0.026). Mean distances between populations ranged from 0.004 between VOLK and CARO to 0.104 between DAD and ROS (Table 4). The Fst value for the mitochondrial sequence data was low and not statistically significant (Fst $=0.14$, $\mathrm{P}>0.05$ ). An AMOVA performed on the mtDNA data revealed that $85.03 \%$ of the genetic variance was explained by intra-population variation, while the remaining $14.93 \%(\mathrm{P}<0.01)$ explained variation among populations. 
Table 2

Ephydrid fly mtDNA COI haplotypes, representing the number of each haplotype $\left(\mathrm{H}_{1-47}\right)$ for each of the South African populations sampled.

\begin{tabular}{|c|c|c|c|c|c|c|c|c|c|c|c|c|c|c|}
\hline Hp No. & $\mathrm{AMF}$ & CAL & CAR & CHR & DAD & $\mathrm{LAB}$ & EIC & ERM & KTD & LVR & ROS & POT & UND & VOL \\
\hline 1 & & & & & & $\mathbf{X}$ & & & & & & & & \\
\hline 2 & & & & & & $\mathbf{X}$ & & & & & & & & \\
\hline 3 & & & & & & $\mathbf{X}$ & & & & & & & & \\
\hline 4 & & & $\mathbf{X}$ & $\mathbf{X}$ & & $\mathrm{X}$ & & $\mathbf{X}$ & & $\mathbf{X}$ & & & & $\mathbf{X}$ \\
\hline 5 & & & & & & & & & & $\mathbf{X}$ & & & & \\
\hline 6 & & & & & & & & $\mathbf{X}$ & & & & & & $\mathbf{X}$ \\
\hline 7 & & & & & & $\mathbf{X}$ & & & & & & & & \\
\hline 8 & & & & & & & & $\mathbf{X}$ & & & & & & \\
\hline 9 & & & & & & & & & & & & & & $\mathbf{X}$ \\
\hline 10 & & & $\mathbf{X}$ & & & & & & & $\mathbf{X}$ & & & & $\mathbf{X}$ \\
\hline 11 & & & & $\mathbf{X}$ & & & & & & & & & & \\
\hline 12 & & & $\mathbf{X}$ & & & $\mathbf{X}$ & & & & $\mathbf{X}$ & & & & \\
\hline 13 & & & & & & & & $\mathbf{X}$ & & & & & & \\
\hline 14 & & & & & & & & & $\mathbf{X}$ & & & & & \\
\hline 15 & & & & & & & & & & & $\mathbf{X}$ & & & \\
\hline 16 & & & & & & & & & & & $\mathbf{X}$ & & & \\
\hline 17 & & & & & $\mathbf{X}$ & & & & & & & & & \\
\hline 18 & & $\mathbf{X}$ & & & & & & & & & & & & \\
\hline 19 & & $\mathrm{X}$ & & & & & & & & & & & & \\
\hline 20 & & & & & & & & & & & & & $\mathbf{X}$ & \\
\hline 21 & & & $\mathbf{X}$ & & & & & & & & & & & \\
\hline 22 & & & & & & & & & & $\mathbf{X}$ & & & & \\
\hline 23 & & & & & $\mathbf{X}$ & & & & & & & & & \\
\hline 24 & & & & & & & & & $\mathbf{X}$ & & & & & \\
\hline 25 & & & & & & & & & $\mathbf{X}$ & & & & & \\
\hline 26 & & & & & & & & & $\mathrm{X}$ & & & & & \\
\hline 27 & & & & & & & & $\mathbf{X}$ & & & & & & \\
\hline 28 & & & & & & & & $\mathbf{X}$ & & & & & & \\
\hline 29 & & & & & & & & $\mathbf{X}$ & & & & & & \\
\hline 30 & & & & & & & & & & & & & $\mathrm{X}$ & \\
\hline 31 & & & & & & & & $\mathbf{X}$ & & & & & & \\
\hline 32 & & & & & & & & $\mathbf{X}$ & & & & & & \\
\hline 33 & & & & & & & $\mathbf{X}$ & & & & & & & \\
\hline 34 & & & & & & & $\mathrm{X}$ & & & & & & & \\
\hline 35 & & & & & & & & & & & & & $\mathrm{X}$ & \\
\hline 36 & & & & & & & & $\mathbf{X}$ & & & & & & \\
\hline 37 & & & & & & & & & & & $\mathrm{X}$ & & & \\
\hline 38 & & & & & & & $\mathbf{X}$ & & & & & & & \\
\hline 39 & & & & & & & & & & & $\mathbf{X}$ & & & \\
\hline 40 & & & & & & & & & & $\mathbf{X}$ & & & & \\
\hline 41 & $\mathbf{X}$ & & & & & & & & & & & & & \\
\hline 42 & $\mathbf{X}$ & & & & & & & & & & & & & \\
\hline 43 & & & & & & & & & & & $\mathrm{X}$ & & & \\
\hline 44 & & & & & & & & & & & $\mathbf{X}$ & & & \\
\hline 45 & & & & $\mathbf{X}$ & & & & & & & & & & \\
\hline 46 & & & & & & & & & & & & $\mathrm{X}$ & & \\
\hline 47 & & & & & & & & & & & & $\mathbf{x}$ & & \\
\hline
\end{tabular}

Table 3

Genetic variability within 14 ephydrid fly populations sampled in South Africa.

\begin{tabular}{lllll}
\hline Population & $n$ & $\mathrm{Hp}$ & $h \pm \mathrm{SD}$ & $\pi \pm \mathrm{SD}$ \\
\hline AMF & 2 & 2 & $1.000 \pm 0.500$ & $0.008 \pm 0.003$ \\
CALA & 3 & 3 & $1.000 \pm 0.272$ & $0.009 \pm 0.003$ \\
CARO & 4 & 4 & $1.000 \pm 0.177$ & $0.006 \pm 0.002$ \\
CHRIS & 3 & 3 & $1.000 \pm 0.272$ & $0.025 \pm 0.015$ \\
DAD & 2 & 2 & $1.000 \pm 0.500$ & $0.118 \pm 0.014$ \\
LAB & 10 & 5 & $0.800 \pm 0.100$ & $0.016 \pm 0.003$ \\
EIC & 5 & 5 & $1.000 \pm 0.126$ & $0.011 \pm 0.003$ \\
ERM & 11 & 9 & $0.964 \pm 0.051$ & $0.007 \pm 0.003$ \\
KTD & 4 & 4 & $1.000 \pm 0.177$ & $0.006 \pm 0.002$ \\
LVR & 8 & 6 & $0.929 \pm 0.084$ & $0.016 \pm 0.004$ \\
ROS & 6 & 6 & $1.000 \pm 0.096$ & $0.057 \pm 0.007$ \\
POT & 2 & 2 & $1.000 \pm 0.500$ & $0.016 \pm 0.008$ \\
UND & 3 & 3 & $1.000 \pm 0.172$ & $0.020 \pm 0.004$ \\
VOLK & 4 & 4 & $1.000 \pm 0.177$ & $0.003 \pm 0.002$
\end{tabular}

Hp, number of haplotypes; h, haplotype diversity; $\pi$, nucleotide diversity.

\subsection{Inter-simple sequence repeats}

The final dataset consisted of 237 fragments for 11 of the 14 locations sampled in South Africa. Fragments ranged in size from 100 to $650 \mathrm{bp}$. All populations had low levels of polymorphism and expected heterozygosity (HE, Nei's gene diversity), with CALA, CARO, KTD and POT considerably lower for both (Table 5). AMOVA of the microsatellite data (for the 10 populations collected on Lagarosiphon species) revealed that $16.55 \%\left(\Phi_{\mathrm{ST}}=0.165, \mathrm{P}<0.01\right)$ of the genetic variation was explained by intra-population variation, while the remaining 83.45\% ( $<<0.01$ ) explained variation between populations (Table 6). Another AMOVA was conducted using the three provinces as groups, however very low differentiation was found among populations, $4.69 \%$ $(\mathrm{P}<0.01)$. The $H$. lagarosiphon individuals collected on Lagarosiphon species are clearly distinguished by PCA, while individuals collected from Potamogeton sp. clustered separately (Fig. 2). Hydrellia sp. on Hydrilla verticillata in South Africa, Hydrellia pakistanae collected on $H$. verticillata in India and Hydrellia purcelli collected on $H$. verticillata in Singapore also reveal three distinct clusters. This is supported by the AMOVA which indicated that $43 \%$ of genetic diversity occurred within populations while the variability among populations collected on different plant families was $57 \%\left(\Phi_{\mathrm{ST}}=0.566, \mathrm{P}<0.01\right)$ (Table 6$)$. 


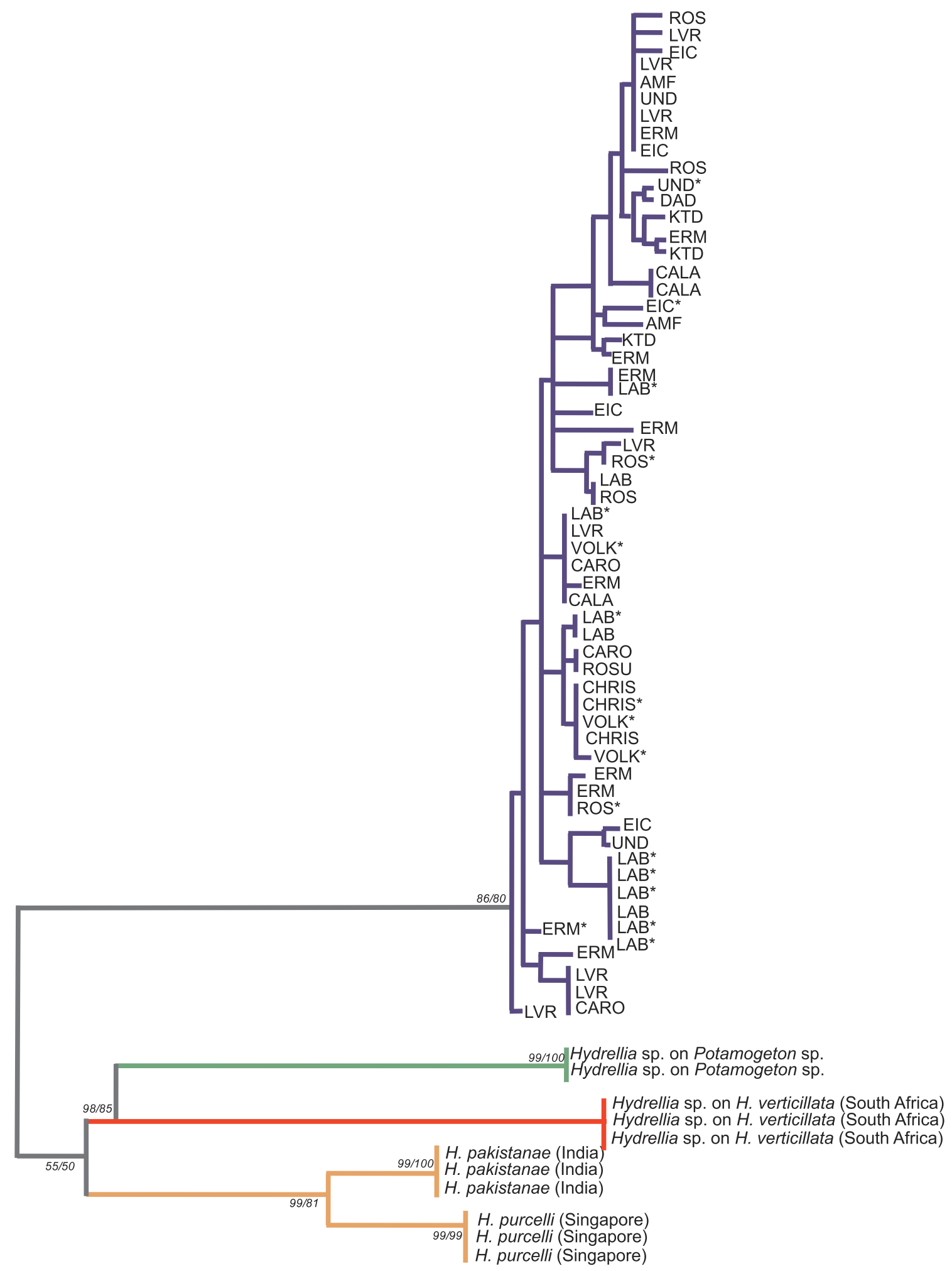

Fig. 1. Maximum likelihood tree using the GTR $+\mathrm{G}$ model of substitution of 47 cytochrome oxidase 1 region haplotypes (608 bp) resolving four major lineages; South African $H$. lagarosiphon samples are indicated in blue, Hydrellia sp. on Potamogeton sp. samples are indicated in green, South African Hydrellia sp. on Hydrilla verticillata are indicated in red and $H$. pakistanae on $H$. verticillata from India and $H$. purcelli on $H$. verticillata Singapore are indicated in yellow. Bootstrap values obtained for major lineages by neighbor joining and maximum likelihood analyses are shown above/below nodes. * Indicates sites where adult flies were also reared from pupae within infested plant material. (For interpretation of the references to colour in this figure legend, the reader is referred to the web version of this article.)

\section{Discussion}

This study reveals high levels of genetic diversity and low levels of genetic differentiation across the individuals collected on Lagarosiphon for both mitochondrial and nuclear markers despite the large geographic distances separating the populations. The high levels of genetic diversity observed appear to be correlated with low Fst values and $\Phi_{\mathrm{ST}}$, suggesting low genetic differentiation between populations of $H$. 
Table 4

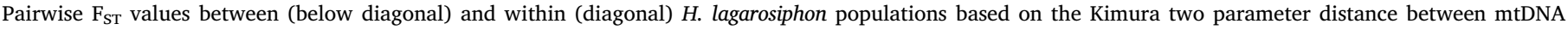
haplotypes.

\begin{tabular}{|c|c|c|c|c|c|c|c|c|c|c|c|c|c|}
\hline Site code & $\mathrm{AMF}$ & CALA & CARO & CHRIS & $\mathrm{DAD}$ & EIC & ERM & KTD & $\mathrm{LAB}$ & LVR & ROS & UND & VOLK \\
\hline $\mathrm{AMF}$ & 0.016 & & & & & & & & & & & & \\
\hline CALA & 0.009 & 0.019 & & & & & & & & & & & \\
\hline CARO & 0.010 & 0.008 & 0.007 & & & & & & & & & & \\
\hline CHRIS & 0.021 & 0.019 & 0.015 & 0.002 & & & & & & & & & \\
\hline $\mathrm{DAD}$ & 0.075 & 0.076 & 0.076 & 0.083 & 0.011 & & & & & & & & \\
\hline EIC & 0.008 & 0.011 & 0.011 & 0.022 & 0.077 & 0.026 & & & & & & & \\
\hline ERM & 0.013 & 0.011 & 0.006 & 0.016 & 0.077 & 0.014 & 0.006 & & & & & & \\
\hline KTD & 0.007 & 0.009 & 0.009 & 0.022 & 0.076 & 0.008 & 0.013 & 0.006 & & & & & \\
\hline LAB & 0.015 & 0.016 & 0.013 & 0.023 & 0.085 & 0.017 & 0.015 & 0.016 & 0.065 & & & & \\
\hline LVR & 0.016 & 0.015 & 0.012 & 0.019 & 0.080 & 0.017 & 0.013 & 0.016 & 0.019 & 0.141 & & & \\
\hline ROS & 0.039 & 0.038 & 0.035 & 0.046 & 0.104 & 0.040 & 0.037 & 0.038 & 0.043 & 0.042 & 0.016 & & \\
\hline UND & 0.011 & 0.013 & 0.014 & 0.026 & 0.079 & 0.012 & 0.018 & 0.011 & 0.020 & 0.020 & 0.043 & 0.008 & \\
\hline VOLK & 0.012 & 0.010 & 0.004 & 0.014 & 0.076 & 0.013 & 0.005 & 0.012 & 0.014 & 0.011 & 0.035 & 0.017 & 0.024 \\
\hline
\end{tabular}

$\mathrm{F}_{\mathrm{ST}}$ values range from 0.0 (no differentiation) to 1.0 (complete differentiation).

Table 5

Population genetic parameter estimates for 11 Hydrellia populations sampled in South Africa using the ISSR data set.

\begin{tabular}{lllll}
\hline Population & $n$ & $\begin{array}{l}\text { No. of } \\
\text { polymorphic } \\
\text { bands }\end{array}$ & $\begin{array}{l}\text { \% polymorphic } \\
\text { bands; }\end{array}$ & $\begin{array}{l}\mathrm{H}_{\mathrm{E}} \text {, expected } \\
\text { heterozygosity (Nei's } \\
\text { gene diversity) (SE) }\end{array}$ \\
\hline AMF & 12 & 46 & $19.41 \%$ & $0.041(0.006)$ \\
CALA & 6 & 15 & $6.33 \%$ & $0.019(0.005)$ \\
CARO & 4 & 8 & $3.38 \%$ & $0.014(0.005)$ \\
CHRIS & - & - & - & - \\
DAD & 10 & 34 & $14.35 \%$ & $0.036(0.006)$ \\
LAB & - & - & - & - \\
EIC & 8 & 29 & $12.24 \%$ & $0.037(0.007)$ \\
ERM & 10 & 39 & $16.46 \%$ & $0.037(0.006)$ \\
KTD & 4 & 12 & $5.06 \%$ & $0.021(0.006)$ \\
LVR & 8 & 39 & $16.46 \%$ & $0.043(0.007)$ \\
ROS & 12 & 38 & $16.03 \%$ & $0.036(0.006)$ \\
POT & 3 & 29 & $2.53 \%$ & $0.011(0.004)$ \\
UND & 10 & 37 & $15.61 \%$ & $0.040(0.007)$ \\
VOLK & - & - & - & - \\
\hline
\end{tabular}

lagarosiphon collected on L. major and L. muscoides. This is further supported by the AMOVA which identified that most of the genetic diversity is within and not between populations. Until recently, genetic screening of biological control agents was not common practice (Paterson et al., 2016; Toševski et al., 2013) and the information presented here provides a valuable insight into the genetic structure of $H$. lagarosiphon, and highlights the apparent absence of cryptic species in South African $H$. lagarosiphon. In addition, the low levels of divergence between the populations suggest there is a higher likelihood that the host ranges of the populations will be similar. However, Paterson et al. (2016) recommend that for potential biological control agents multiple populations of the same species are screened separately to avoid unpredicted non-target effects. Host specificity testing, carried out on the Kubusi farm dam population, show that $H$. lagarosiphon is specific to Lagarosiphon and poses no threat to either exotic or native plants in the order Alismatales in Ireland and New Zealand (Mangan, 2013; Baars and Paynter, 2014). However, further host testing will be required should the release of any additional populations of $H$. lagarosiphon be pursued.

Fry and Zink (1998) suggest that a lack of geographic structure in rapidly evolving molecular markers, such as mtDNA, implies high levels of gene flow. However, it is also possible that low Fst values (as observed here) may be indicative of high levels of polymorphism even where gene flow is reduced (Jin and Chakraborty, 1995). The large distance $(>1000 \mathrm{~km}$ ) between the Eastern Cape and Mpumalanga sites in particular, separated by mountain ranges (Drakensberg Mountains) which form natural geographic barriers, would potentially inhibit the natural movement of $H$. lagarosiphon between these regions. However, L. major and L. muscoides proliferate in man-made dams and impoundments throughout the country (Baars et al., 2010) and networks of impoundments, such as those found across South Africa, can drastically alter the distribution of freshwater ecosystems, even across large spatial scales (Johnson et al., 2008). These networks provide the potential for increased connectivity and mobility of $H$. lagarosiphon between sites, resulting in high levels of gene flow, which highlights the potential for quick and efficient spread of $H$. lagarosiphon, should it be released into new environments as a control measure for L. major (Jonsen et al., 2007; Rauth et al., 2011). Promisingly, the release of the closely related Hydrellia pakistanae in Florida U.S.A., resulted in wide dispersal and establishment of the fly throughout the majority of $\mathrm{Hy}$ drilla-infested water bodies in the state, which was in part attributed to the fly's natural dispersal capabilities (Center, 1997).

The high levels of genetic diversity and population admixture, combined with low levels of genetic differentiation do not support

Table 6

AMOVA output of $H$. lagarosiphon ISSR data for (A) 10 populations collected on Lagarosiphon species, (B) for the same populations across the three provinces and, (C) the blue and green clusters characterized by the principal component analysis (see Fig. 2).

\begin{tabular}{|c|c|c|c|c|c|c|c|}
\hline & Source & SS & d.f. & Variance component & $\%$ variance & $\Phi_{\mathrm{ST}}$ & $\mathrm{P}$ \\
\hline \multirow[t]{3}{*}{ A } & Within populations & 508.650 & 72 & 7.065 & 83.45 & 0.165 & 0.001 \\
\hline & Among populations & 165.679 & 9 & 1.401 & 16.55 & & \\
\hline & Total & 674.329 & 81 & 8.466 & & & \\
\hline \multirow[t]{3}{*}{ B } & Within populations & 638.666 & 79 & 8.084 & 95.30 & 0.04 & 0.001 \\
\hline & Among populations & 35.663 & 2 & 0.398 & 4.69 & & \\
\hline & Total & 674.329 & 81 & 8.482 & & & \\
\hline \multirow[t]{3}{*}{ C } & Within populations & 678.329 & 83 & 8.173 & 43.36 & 0.566 & 0.000 \\
\hline & Among populations & 69.953 & 1 & 10.673 & 56.64 & & \\
\hline & Total & 748.282 & 84 & 18.846 & & & \\
\hline
\end{tabular}




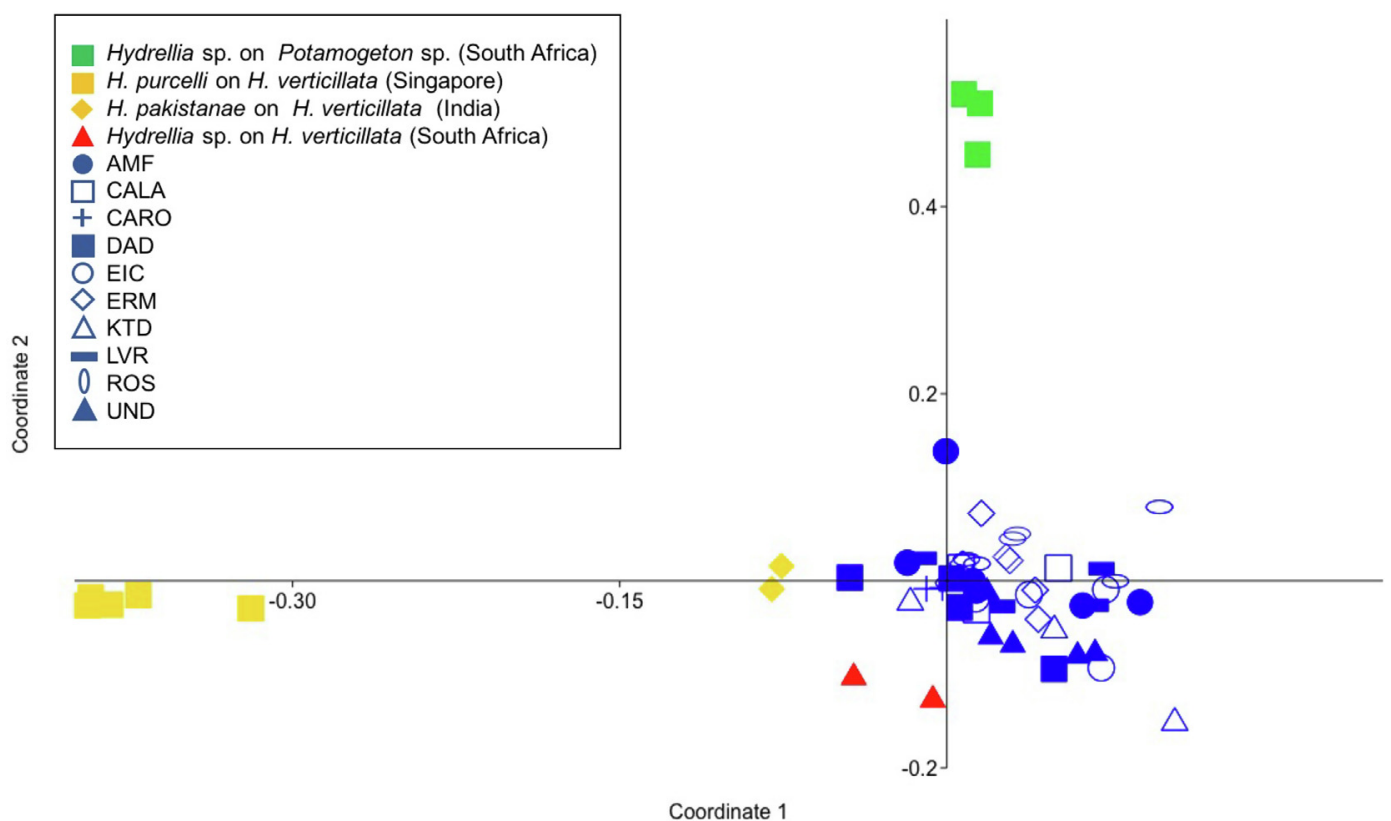

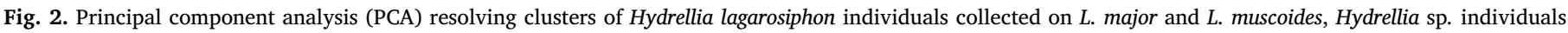
collected on Potamogeton sp. and $H$. pakistanae and $H$. purcelli collected on $H$. verticillata.

genetic divergence by isolation. As a result, evidence of local adaptation and potential performance differences between populations originating from different parts of South Africa are unlikely. Preliminary data collected on the performance of three populations from different ecoregions (Kubusi farm dam in the Eastern Cape, Chrissiesmeer in Mpumalanga, and Volksrust farm dam near the Mpumalanga-KwaZuluNatal border) support these findings, with no significant differences evident for the reproductive development or thermal tolerances of $H$. lagarosiphon (Earle and Baars, 2011). These data suggest that none of the ecoregion-specific populations are favorably adapted to low temperature ranges and the selection of a particular population as the founder as a biocontrol agent stock will not confer any developmental performance benefit. Encouragingly, the colonization potential of the Kubusi farm dam (LAB) population has been evaluated, and results indicate that although climate may be a potential limiting factor affecting the colonization success of $H$. lagarosiphon in certain areas, most biogeographical regions in Europe appeared suitable for the establishment of permanent populations of the fly (Mangan and Baars, 2013).

Maintaining a high level of genetic diversity within a field-released population is also an important step in successful biocontrol establishment, as it is likely to increase the probability of survival, local adaptation, and breeding after establishment in the field (Angalet et al., 1979; Lloyd et al., 2005; Reed and Frankham, 2001). One method of facilitating establishment success of an introduced species is to cross genetically differentiated populations (Rius and Darling, 2014). This approach can increase genetic diversity, create new genotypes and mask recessive deleterious mutations (Frankham, 2005; Li et al., 2018), and was common practice in the early 1990s (Paynter et al., 2008). However, it is no longer a recommended policy as the prediction of the long-term dynamics under field conditions, in particular host range evolution, can be extremely difficult (Futuyma et al., 1995). Large founder populations of a single consignment are therefore preferable, which reduce the probability of a genetic bottleneck (Taylor et al., 2011), and increase the likelihood of sampling a genetically diverse stock population during host specificity testing (Rauth et al., 2011). The rearing technique adopted by our group, of frequently transferring individuals between culture cages to avoid inbreeding and to maximise genetic diversity, has resulted in vigorous population growth since the establishment of laboratory cultures in 2009 and this population has maintained substantial genetic variation over this time.
The results of our study highlight the benefits of using molecular genetics to obtain a better understanding of population-level genetic structure and variation in potential biocontrol agents. In addition to identifying cryptic species, genetic analysis, as shown here, can identify potential variation (or lack thereof) in an agent's climatic adaptation or host-related traits and can predict the potential for effective dispersal into new environments. Such information is essential to the selection and efficient use of any potential biological control agent and we support the recommendation of adopting molecular genetic analyses as a prerequisite for any future biocontrol assessment programmes that wish to maximise the efficiency and potential success of newly released agents.

\section{Author statement}

R.M., J.C.C., and J.-R.B. conceived the experiments. R.M. and J.C.C. contributed to sample preparation and planned the experiments. R.M. carried out the experiments, conducted the analysis and prepared the manuscript. All authors provided critical feedback and helped shape the final manuscript.

\section{Acknowledgements}

We gratefully acknowledge the ongoing help we have received from the staff of Inland Fisheries Ireland and the assistance provided by colleagues in the Department of Zoology and Entomology, Rhodes University, South Africa. Funding was provided by the Irish Research Council, the CAISIE Project EU Life + Programme, and the South African Research Chairs Initiative of the Department of Science and Technology and the National Research Foundation of South Africa.

\section{References}

Abbot, P., 2001. Individual and population variation in invertebrates revealed by intersimple sequence repeats (ISSRs). J. Insect Sci. 1, 8.

Angalet, G.W., Tropp, J.M., Eggert, A.N., 1979. Coccinella septempunctata1 in the United States: recolonizations and notes on its ecology. Environ. Entomol. 8, 896-901.

Arrigo, N., Tuszynski, J.W., Ehrich, D., Gerdes, T., Alvarez, N., 2009. Evaluating the impact of scoring parameters on the structure of intra-specific genetic variation using RawGeno, an R package for automating AFLP scoring. BMC Bioinf. 10, 33.

Assoumane, A., Zoubeirou, A.M., Rodier-Goud, M., Favreau, B., Bezançon, G., Verhaegen, 
D., 2013. Highlighting the occurrence of tetraploidy in Acacia senegal (L.) Willd. and genetic variation patterns in its natural range revealed by DNA microsatellite markers. Tree Genet. Genomes 9, 93-106.

Baars, J.-R., Coetzee, J.A., Martin, G., Hill, M.P., Caffrey, J.M., 2010. Natural enemies from South Africa for biological control of Lagarosiphon major (Ridl.) Moss ex Wager (Hydrocharitaceae) in Europe. Hydrobiologia 656, 149-158.

Baars, J.-R., Paynter, Q., 2014. Host range tests of Hydrellia lagarosiphon a candidate agent for Lagarosiphon major in New Zealand: assessing the risk to non-target species in New Zealand. Landcare Research Report, New Zealand.

Behura, S.K., 2006. Molecular marker systems in insects: current trends and future avenues. Mol. Ecol. 15, 3087-3113.

Bigler, F., Bale, J., Cock, M., Dreyer, H., Greatrex, R., Kuhlmann, U., Loomans, A., Van Lenteren, J.J.B.N., 2005. Guidelines on information requirements for import and release of invertebrate biological control agents in European countries. Biocontrol News Inf. 26, 115N-123N.

Bowmer, K.H., Jacobs, S.W.L., Sainty, G.R., 1995. Identification, biology and management of Elodea canadensis, Hydrocharitaceae. J. Aquat. Plant Manag. 33, 13-19.

Center, T.D., 1997. Establishment of Hydrellia pakistanae (Diptera: Ephydridae) for the biological control of the submersed aquatic plant Hydrilla verticillata (Hydrocharitaceae) in the southeastern United States. Biol. Control 8, 65-73 v.1998 no.1991.

Deeming, J.C., 2012. A new species of Hydrellia Robineau-Desvoidy (Diptera: Ephydridae) developing in Lagarosiphon major (Hydrocharitaceae) in South Africa. Afr. Entomol. 20, 217-221.

Earle, W., Baars, J.-R., 2011. Targeting ecotypes of Hydrellia lagarosiphon in pre-release studies using adult longevity, reproductive performance and temperature tolerance. In: Wu, Yun, Johnson, Tracy, Sing, Sharlene, Raghu, S., Wheeler, Greg, Pratt, Paul, Warner, Keith, Center, Ted, Goolsby, John, Reardon, Richard (Eds.), Proceedings of the XIII International Symposium on Biological Control of Weeds; September 11-16, 2011. U.S. Department of Agriculture, Forest Service, Forest Health Technology Enterprise Team, 2012-07, Waikoloa, Hawaii, USA, pp. 54

Earle, W., Mangan, R., O'Brien, M., Baars, J.-R., 2013. Biology of Polypedilum n. sp. (Diptera: Chironomidae), a promising candidate agent for the biological control of the aquatic weed Lagarosiphon major (Hydrocharitaceae) in Ireland. Biocontrol Sci. Technol. 23, 1267-1283.

Excoffier, L., Laval, G., Schneider, S., 2005. Arlequin (version 3.0): an integrated software package for population genetics data analysis. Evol. Bioinf. 1117693430500100003.

Excoffier, L., Smouse, P.E., Quattro, J.M., 1992. Analysis of molecular variance inferred from metric distances among DNA haplotypes: application to human mitochondrial DNA restriction data. Genetics 131, 479-491.

Frankham, R., 2005. Genetics and extinction. Biol. Conserv. 126, 131-140.

Fry, A.J., Zink, R.M., 1998. Geographic analysis of nucleotide diversity and song sparrow (Aves: Emberizidae) population history. Mol. Ecol. 7, 1303-1313.

Futuyma, D.J., Keese, M.C., Funk, D.J., 1995. Genetic constraints on macroevolution: the evolution of host affiliation in the leaf beetle genus Ophraella. Evolution 49, 797-809.

Gariepy, T.D., Kuhlmann, U., Gillott, C., Erlandson, M., 2007. Parasitoids, predators and PCR: the use of diagnostic molecular markers in biological control of Arthropods. J. Appl. Entomol. 131, 225-240.

Goolsby, J.A., Van Klinken, R.D., Palmer, W.A., 2006. Maximising the contribution of native range studies towards the identification and prioritisation of weed biocontrol agents. Aust. J. Entomol. 45, 276-286.

Hammer, Ø., Harper, D.A.T., Ryan, P.D., 2001. PAST-Palaeontological statistics. www. uv. es/ pardomv/pe/2001_1/past/pastprog/past. pdf, acessado em 25, 2009.

Herbert, P.D.N., Penton, E.H., Burns, J.M., Janzen, D.H., Hallwachs, W., 2004. Ten species in one: DNA barcoding reveals cryptic species in the neotropical skipper butterfly Astraptes fulgerator. Proc. Natl. Acad. Sci. U.S.A. 101, 14812-14817.

Hopper, K.R., Roush, R.T., 1993. Mate finding, dispersal, number released, and the success of biological control introductions. Ecol. Entomol. 18, 321-331.

Hudson, R.R., Slatkin, M., Maddison, W.P., 1992. Estimation of levels of gene flow from DNA sequence data. Genetics 132, 583-589.

Hufbauer, R.A., Bogdanowicz, S.M., Harrison, R.G., 2004. The population genetics of a biological control introduction: mitochondrial DNA and microsatellie variation in native and introduced populations of Aphidus ervi, a parisitoid wasp. Mol. Ecol. 13, 337-348.

Hufbauer, R.A., Roderick, G.K., 2005. Microevolution in biological control: mechanisms, patterns, and processes. Biol. Control 35, 227-239.

Jin, L., Chakraborty, R., 1995. Population structure, stepwise mutations, heterozygote deficiency and their implications in DNA forensics. Heredity (Edinb.) 74, 274.

Johnson, P.T.J., Olden, J.D., Vander Zanden, M.J., 2008. Dam invaders: impoundments facilitate biological invasions into freshwaters. Front. Ecol. Environ. 6, 357-363.

Jonsen, I.D., Bourchier, R.S., Roland, J., 2007. Influence of dispersal, stochasticity, and an Allee effect on the persistence of weed biocontrol introductions. Ecol. Modell. 203, 521-526.

Kimura, M., 1980. A simple method for estimating evolutionary rates of base substitutions through comparative studies of nucleotide sequences. J. Mol. Evol. 16, 111-120.

Li, H.-S., Zou, S.-J., De Clercq, P., Pang, H., 2018. Population admixture can enhance establishment success of the introduced biological control agent Cryptolaemus montrouzieri. BMC Evol. Biol. 18, 36.

Librado, P., Rozas, J., 2009. DnaSP v5: a software for comprehensive analysis of DNA polymorphism data. Bioinformatics 25, 1451-1452.

Lloyd, C.J., Hufbauer, R.A., Jackson, A., Nissen, S.J., Norton, A.P., 2005. Pre-and postintroduction patterns in neutral genetic diversity in the leafy spurge gall midge,
Spurgia capitigena (Bremi)(Diptera: Cecidomyiidae). Biol. Control 33, 153-164.

Madeira, P., Hale, R., Center, T., Buckingham, G., Wineriter, S., Purcell, M.J.B., 2001. Whether to release Oxyops vitiosa from a second Australian site onto Florida's melaleuca? a molecular approach. Biocontrol 46, 511-528.

Mangan, R., 2013. Pre-release evaluation studies of the leaf-mining fly, Hydrellia lagarosiphon (Diptera: Ephydridae) a candidate biological control agent of the submerged aquatic invasive weed Lagarosiphon major (Hydrocharitaceae). PhD thesis. University College Dublin, Ireland.

Mangan, R., Baars, J.-R., 2013. Use of life table statistics and degree day values to predict the colonisation success of Hydrellia lagarosiphon Deeming (Diptera: Ephydridae), a leaf mining fly of Lagarosiphon major (Ridley) Moss (Hydrocharitaceae), in Ireland and the rest of Europe. Biol. Control 64, 143-151.

McGregor, P.G., Gourlay, H., 2002. Assessing the prospects for biological control of lagarosiphon (Lagarosiphon major (Hydrocharitaceae)). DOC Science Internal Series 57 Department of Conservation, Wellington, $14 \mathrm{p}$

Moffat, C.E., Smith, M.A., 2015. Pre-release detection of a biocontrol agent: combining independent and public DNA sequences to identify the first North American record of Aulacidea pilosellae (Hymenoptera: Cynipidae). Can. Entomol. 147, 390-395.

Mound, L.A., Wheeler, G.S., Williams, D.A., 2010. Resolving cryptic species with morphology and DNA; thrips as a potential biocontrol agent of Brazilian peppertree, with a new species and overview of Pseudophilothrips (Thysanoptera). Zootaxa 2432, 59-68.

Olivieri, I., Singer, M.C., Magalhaes, S., Courtiol, A., Dubois, Y., Carbonell, D., Justy, F., Beldade, P., Parmesan, C., Michalakis, Y., 2008. Genetic, ecological, behavioral and geographic differentiation of populations in a thistle weevil: implications for speciation and biocontrol. Evol. Appl. 1, 112-128.

Paterson, I.D., Mangan, R., Downie, D.A., Coetzee, J.A., Hill, M.P., Burke, A.M., Downey, P.O., Henry, T.J., Compton, S.G., 2016. Two in one: cryptic species discovered in biological control agent populations using molecular data and crossbreeding experiments. Ecol. Evol. 6, 6139-6150.

Paynter, Q., Gourlay, A.H., Oboyski, P.T., Fowler, S.V., Hill, R.L., Withers, T.M., Parish, H., Hona, S., 2008. Why did specificity testing fail to predict the field host-range of the gorse pod moth in New Zealand? Biol. Control 46, 453-462.

Peakall, R.O.D., Smouse, P.E., 2006. GENALEX 6: genetic analysis in Excel. Population genetic software for teaching and research. Mol. Ecol. Notes 6, 288-295.

Preston, C.D., Pearman, D., Dines, T.D., 2002. New atlas of the British \& Irish flora, Oxford University Press.

Rambaut, A., 2001. Se-Al: Sequence Alignment Editor ver. 2.0. Á Oxford Dept. of Zool, Univ. of Oxford.

Rauth, S.J., Hinz, H.L., Gerber, E., Hufbauer, R.A., 2011. The benefits of pre-release population genetics: a case study using Ceutorhynchus scrobicollis, a candidate agent of garlic mustard, Alliaria petiolata. Biol. Control 56, 67-75.

Reed, D.H., Frankham, R., 2001. How closely correlated are molecular and quantitative measures of genetic variation? a meta-analysis. Evolution 55, 1095-1103.

Reynolds, S.C.P., 2002. A catalogue of alien plants in Ireland. A catalogue of alien plants in Ireland.

Rius, M., Darling, J.A., 2014. How important is intraspecific genetic admixture to the success of colonising populations? Trends Ecol. Evol. 29, 233-242.

Roderick, G.K., Navajas, M., 2003. Genes in new environments: genetics and evolution in biological control. Nat. Rev. Genet. 4, 889.

Simon, C., Frati, F., Beckenbach, A., Crespi, B., Liu, H., Flook, P., 1994. Evolution, weighting, and phylogenetic utility of mitochondrial gene sequences and a compilation of conserved polymerase chain reaction primers. Ann. Entomol. Soc. Am. 87, 651-701.

Slatkin, M., 1985. Rare alleles as indicators of gene flow. Evolution 39, 53-65.

Smith, M.A., Woodley, N.E., Janzen, D.H., Hallwachs, W., Heibert, P.D.N., 2006. DNA barcodes reveal cryptic host-specificity within the presumed polyphagous members of a genus of parasitoid flies (Diptera: Tachinidae). Proc. Natl. Acad. Sci. 103, 3657-3662.

Symoens, J.J., Triest, L., 1983. Monograph of the African Genus Lagarosiphon Harvey (Hydrocharitaceae). Bull. Jard. Bot. Belg./Bulletin van de National Plantentuin van België 53, 441-488.

Tamura, K., Peterson, D., Peterson, N., Stecher, G., Nei, M., Kumar, S., 2011. MEGA5: molecular evolutionary genetics analysis using maximum likelihood, evolutionary distance, and maximum parsimony methods. Mol. Biol. Evol. 28, 2731-2739.

Taylor, S.J., Downie, D.A., Paterson, I.D., 2011. Genetic diversity of introduced populations of the water hyacinth biological control agent Eccritotarsus catarinensis (Hemiptera: Miridae). Biol. Control 58, 330-336.

Toševski, I., Jović, J., Krstić, O., Gassmann, A., 2013. PCR-RFLP-based method for reliable discrimination of cryptic species within Mecinus janthinus species complex (Mecinini, Curculionidae) introduced in North America for biological control of invasive toadflaxes. Biocontrol 58, 563-573.

Van Achterberg, C., Prinsloo, G.L., 2012. Braconidae (Hymenoptera: Opiinae, Alysiinae) reared from aquatic leaf-mining Diptera on Lagarosiphon major (Hydrocharitaceae) in South Africa. Afr. Entomol. 20, 124-133.

Van Driesche, R., Bellows, T.S., 1996. Biological Control. Chapman \& Hall, New York.

van Valkenburg, J.L.C.H., Pot, R., 2008. Lagarosiphon major (Ridl.) Moss (Verspreidbladige waterpest) nu ook gevestigd in de Groene Ruimte in Nederland. Gorteria 33, 89-92.

Vorsino, A.E., Wieczorek, A.M., Wright, M.G., Messing, R.H., 2014. Genetic analysis of an introduced biological control agent reveals temporal and geographic change, with little evidence of a host mediated shift. Biol. Control 77, 41-50. 